\title{
Russia Domination Policy: Implementation of Military Operation in Ukraine
}

(2014- 2015)

Hendra Manurung ${ }^{1}$

\begin{abstract}
Abstrak
Federasi Rusia merupakan aktor global yang menerapkan kebijakan tegas terhadap Ukraina. Guna mencapai tujuan politik nasional Rusia yang dikendalikan dari Moskwa, melalui operasi militer di tahun 2014, didefinisikan bagaimana negara tersebut berperilaku. Melalui kombinasi operasi militer dan non-militer, Rusia secara perlahan memperoleh kekuasaan melalui aneksasi Krimea. Efektivitas metoda ini dipergunakan untuk menentukan strategi perang Rusia saat ini. Dengan demikian menjelaskan bagaimana kebijakan luar negeri dan kebijakan pertahanan Rusia dari tahun 2000 hingga 2013 yang memiliki ketergantungan pada lingkungan strategis Ukraina terhadap Rusia, dan kepentingan nasional Rusia pada Ukraina. Fokus utama penelitian ini adalah pencapaian tujuan politik Rusia dalam operasi militer yang dilaksanakan di Ukraina dan menganalisa komponen keamanan nasional Rusia yang signifikan mempengaruhi interaksi konflik asimetrik.
\end{abstract}

Kata-kata kunci: keamanan nasional, tujuan politik, operasi militer, perilaku negara Abstract

Russia Federation as global actor applied its policies towards Ukraine remains assertive. In pursuing state's political objectives from Moscow, the escalation of military operation in 2014 defined as the way on how the state behaves. By means of the combination of military and non-military measures on the conduct of operation, Russia is now slowly regaining its power through the annexation of Crimea. The effectiveness of this method determines to be Russia's strategy on contemporary warfare. Thus, it explains how Russian foreign and defense policy from 2000 to 2013 that depend on surrounding strategic environment of Ukraine to Russia, and the national interests of Russia to Ukraine. The main focus of this research is on the achievement of Russia's political objective in its military operation in Ukraine and analysis on Russia's national security components that are significantly influence the interaction of this asymmetric conflict.

Keywords: national security, political objectives, military operations, state’s behavior

\section{Introduction}

Major states often exercise their military operation as the strategy to pursuit their objectives. The acts systematically identified as the behavior of states during war time. The outcome of such action encourages the international system to formulate an institution that could maintain the world order, where it known as the United Nations (UN). In January 1946, the four major states (Britain, France, Russia, and the United States) who were often exercising military operation met for the first time as the permanent members of the United Nations Security Council. Despite as the immediate effects from World War II, these states power have tendency to implies victory in war, they need to maintain their existence in the international system cooperatively and competitively. Although the promotion of the ideas of the UN has been introduce, the military activities are still continuously conducted by those major states

\footnotetext{
${ }^{1}$ Lecturer of International Department at President University. Email: h_manurung2002@president.ac.id
} 
in the next decades. Their ability in the conduct of military operations are adequate quantity in achieving the objectives(Volt, 2001). Thus, the operations often found as strategic tools of a state in pursing their interests because it remains as the capability of states' power in pursuing its objectives on certain condition.

The world's atmosphere was dramatically changed when the two great powers, between the Union of Soviet Socialist Republics (USSR) and the United States (U.S.) came into competition in the second half of the 20th century, known as the Cold War. During this period, the establishment of mutual assistance was prominent in international security architecture. The willingness of states to be a dominant actor in the international system is also important. As the result, one of the major states (the Soviet Union) during this period established a security alliance known as the Warsaw Pact. The Warsaw Pact was a formed of political and military alliance under Soviet Union direction in affirming its control over military forces in the region as well as to counterbalance to North AtlantiTreaty Organization (NATO) on the European contingent (Curtis, 1992). After inking the treaty, with the support of Soviet foreign policy, Brezhnev Doctrine - "Doctrine of Limited Sovereignty", declared that when forces that are hostile to socialism try to revert the development of some socialist country towards the restoration of the capitalist order, it becomes not only a problem of the country concerned, but also a common problem and concern of all socialist countries (Brezhnev, 1968). Under this security paradigm, as a strong actor (the Soviet Union) often did military operations towards weak actors (postSoviet space) in order to keep their influence towards the opposing state. As such, the strategic interaction is classified as the study of asymmetric conflict in international relations where the strong actor should almost always win in every conflict based on its victory (Toft, no year)

The security structure of the Soviet Union as major state slowly changes. After expel of Albania in 1962, the organizational structure of this alliance had been modified. The reunification of Germany in 1990, the rise of non-communist government, such as Poland and Czechoslovakia in 1990 and 1991, confirmed the demise of the Warsaw Pact and marked the end of the Cold War as well. Hence, with the emergence of independence states of former Soviet Union, it has shown the decline of state capability to control. At the moment of Soviet state dissolution, Russia consistently preserving its national security and showing its capability as a major state 
throughout various formulation of her domestic and foreign policies.

After the dismissal of the Soviet Union in 1990, the relations between Russia and former Soviet states remain unstable. Russia keeps maintaining its dominant within these countries through various economic, political, and even military activities until today. Along with her foreign policy priority, the aims to establish a Eurasian integration along with (Commonwealth of Independence States) CIS (Ministry of Foreign Affairs, 2013), space has restore Russia to has a proactive approach towards these countries. The basis of Russia priority in the region is not only base on sharing generic historical background, but to build regional integration in various spheres along with the CIS Member States through bilateral and multilateral cooperation (Ministry of Foreign Affairs, 2013).

The concept of foreign policy of the Russian Federation, especially on paragraph 48 (e), it stated that: build up relations with Ukraine as a priority partner within the CIS, contribute to its participation in extended integration processes (Ministry of Foreign Affairs, 2013). The importance of Ukraine on Russia's border is undeniable. The aforementioned situation is in line with a statement from Henry Kissinger statement in an open editorial in the Washington Post that
"To Russia, Ukraine can never be just a foreign country" (Kissinger, 2014). Therefore, the conflict occurring between Russia and Ukraine within Ukraine's territory in 2014 is reflecting the importance of Ukraine for Russia domination in the region. Based on Russia's movement towards the country, it illustrated a new generation of war from Russia's approach today. This pattern of interactions has demonstrated the concept of asymmetric warfare which has been exist long time ago. For instance, as the sage of warfare theory, Tsun Tzu, on his work The Art of War determined that all warfare is based on deception. When confronted with an enemy one should offer the enemy a bait to lure him; feign disorder and strike him. When he concentrates, prepare against him; where he is strong, avoid him (Griffith, 1971: 66-67). It identified tactical strategy in facing the adversaries' strength and advocates it into indirect approach.

Russia respects the universal standards of human rights and democracy as main principles that must be non-violently interpreted by means of different cultural traditions, which is the case in the Western democracies which used traditions and cultural heritages in order to develop domestically sustainable interpretations of international agreements and diplomatic relations. 
It creates dilemmatic relations between Russia and the broader West which strained on numerous occasions since the collapse of the USSR. Yet fears of a new Cold War have been given added impetus have come to perceive as a game-changing event. It refers to Russia's annexation of the Crimean Peninsula in 2014, and its subsequent thinly disguised assistance for separatists in the industrialized Donbas region of Eastern Ukraine. Whereas previous points of tension between Russia and the West have given rise to predictions of renewed rivalry, none of them prior to the crisis in Ukraine had resulted in the actual aggrandizement of territory by the Russian Federation. This was true of Kosovo in 1999, the two wars in Chechnya, and the brief war with Georgia over South Ossetia in 2008 (Sussex and Kaneth, 2013: 2).

Indeed Russia expands its territory since 2014 to 2015. The conflict in Ukraine had significant repercussions for regional order, especially in terms of institutional arrangements, the politics of energy and resources, as well as great power competition

\section{Russia Geopolitics in Ukraine}

The loss of Ukraine in 1991 has also ultimately marked the decline of Russia control over this state. With the changing of security structure after the Cold War, it adjusts both states interaction. The political instability in Ukraine on the year of 2014 has sent a significant challenge for Russia's national security, especially towards Crimea as its naval base. That matter has jeopardized Russia vital interest near Black Sea, so it influences the formulation of strategy towards Ukraine, where Russia needs to use its military operation for its interest's protection. As a major state, Russia needs to maintain national security from possible external hazards to maintain its control over Ukraine.

It highlights analysis of the current Russian political discourse monitored by Moscow which focuses on one aspect of its normative dimension, namely the ideal of national sovereignty and anti-colonial resistance. Kremlin decision makers' resistance can be shaped and is actually shaped in many different ways. As any other vision of liberation, it is used both by the oppressed and the oppressors.

Russia is much concerned by the developments of the United States and the European Union Foreign Policies that seem to believe that they have the right to interfere in other states' internal affairs. Lavrov also indicated that this self-proclaimed right is often justified by the Western leaders in terms of political and ideological superiority of the West. Lavrov stressed that the Russian position, for example in relation to the so 
called "Arab spring", is based on the fundamental Principles of International Law depends on national sovereignty and noninterference. Commenting on the situation in Syria during the spring 2013, Lavrov further confirms that in most of the cases military solutions "could only mean radicalization of the country" (Glasser, 2013).

It is easy to demonstrate how Lavrov's view on international politics presented in the interview fits very well into the tradition of just war ethics as well as it includes an articulated normative vision of how the international system of human rights should be sustained (Glasser, 2013). The Russian concept of foreign policy points out some additional normative concerns in promoting Russia's approach to Human Rights issues transparently and pragmatic. It leads to Russia global competition on a civilizational level, whereby various values and models of development based on the universal principles of democracy and market economy start to clash and compete against each other in Eastern Europe.

Therefore, with the condition as an independence state, during Yanukovych presidency (2010-2014), several tensions have taken place in the relations between Moscow and Kyiv. One of the cases is where Kyiv has built a close relationship with European Union (EU). The Ukraine and EU work on an association agreement-aiming at political association which adhering European values and principles and economic integration for last few years. It is challenging the national security of Russia as a major state in the region. As the result, before it was due to signed, Yanukovych rejected the agreement on November 2013. After several identification conducted, one of the reason behind this agenda is that Russia successfully implemented its political and economic leverage over Ukraine in order to cancel its agreement with EU. There has been an economic instability between Kyiv and Moscow trade relations. Russia has putted a sanction over Ukraine in mid-August. Cutting energy supply to Ukraine and blocking the flow of imports from the country have affecting the economic condition of Ukraine. In accordance to the Wall Street Journal, "Ukrainian officials say the Russian sanctions cost them US\$15 billion in lost trade and it could run up to half a trillion by signing the EU deal" (The Wall Street Journal, 2013). As the result of rejection of agreement, it caused big street protests from pro-Western protesters in Kyiv's Independence Square continuously. On 22 February 2014, a peak demonstration occurred when protesters took control over government building in Kyiv. This situation resulted in Yanukovych fled from Kyiv to eastern part city of Ukraine, Kharkiv, in asking 
for support (The Wall Street Journal, 2013).

The security instability in Ukraine, on February 27, 2014, a penetration over Crimea was executed in the capital of Simferopol, with approximate number of 120 armed Russian insurgents armed with automatic weapons seized the Crimean parliament (Ukrainian Policy, 2014). The signification of occupation then marked with Russian flag flies over Crimea's parliament (The Wall Street Journal, 2013). This condition has put a high tension on the violation of Ukraine territory in regards to Russian invasion which absolutely occurring. Moreover, it was also followed by a statement from the Ukrainian Acting President, Turchynov stated that:

\begin{abstract}
"Russia has begun wanton aggression against Ukraine under the guise of training exercise. The Russian Federation has sent troops into Crimea, and has not only captured the Crimean parliament and Council of Ministers, but also has taken control of communication facilities [...] We're sure that Ukraine will preserve its territory, Ukraine will defend its independence and any attempts of annexation or intrusion will have very serious consequences" (Ukrainian Policy, 2014).
\end{abstract}

On May 2014, a new president of Ukraine, Petro Poroshenko is being elected where at the same time the conflict occurred is still continuously. This president known has long supported the country's pro-European movement (BBC News, 2014). Due to this political challenge, Russia once again is exercising its military operation into Crimea in order to protect the Black Sea Fleet on the ground (Ukrainian Policy, 2014). Therefore, as the strategic interest of Russia, such military operations are conducted in Crimea. This operation has established a strategic interaction between Russia and Ukraine in achieving their political objectives. The interaction is being identified as the asymmetric warfare between strong actor (Russia) and weak actor (Ukraine) in winning their survival.

A strategic interaction between the two countries in Ukraine is reflecting on how a strong state (Russia) is trying to defeat a weak state (Ukraine) through military operations which conducted periodically. It is in line with how Carl von Clausewitz understanding the fact about warfare that it must waged the political objective:

\begin{abstract}
"We see, therefore, that war is not merely an act of policy but a true political instrument, a continuation of political intercourse, carried on with other means. War in general, and the commander in any specific instance, is entitled to require that the trend and designs of policy shall not be inconsistent with these means. That, of course is no small demand, but however much it will affect political aims in a given case, it will never do more than modify them. The political object is the goal, war is the means of reaching it, and means can never be considered in isolation from their purpose" (Clausewitz, 1827).
\end{abstract}

The Cold War remains echoing in the case of Ukraine as a formerly part of Soviet Union. In order to protect its national security and achieving the political objective, Russia implies its victory as a strong actor by 
conducting military operations in Ukraine. As the response, Ukraine is also conducting several operations and tactics based to overcome the challenge. Therefore, the relative power occurred within this pattern is explaining the logic of the asymmetric war between Russia and Ukraine. With various operations and tactics executed from both sides, the relative power owned will later explains the relative interests of the state on how they should response. As such, the strategic interactions that happened during conflict could determine the outcome of relative power.

\section{Russia Strategy in Regional Security}

Russia has reinvented its national policy, which is all about economic cooperation and joint energy projects rather than territorial disputes. Even further afield, Vietnam has shown an increasing interest in Russia, expressing its enthusiasm for being involved with Russia's recently launched Eurasian Union in Asia Pacific economic integration.

Despite the legacy of Soviet might, the degree of trust towards Russia in the Asia Pacific is symbolically revealed in the reaction to Russia's modernization of its Pacific Fleet. Whereas China's re-fitting of an ancient aircraft carrier caused a flurry of intensely negative coverage, there has been little fuss or outcry in this region about the procuring of two state of the art Mistral assault ships which will enter service in 2014 (Manurung, 2013).

Even though this perception of Russia in the region as non-threatening could be a great opportunity for the Russian leadership in Kremlin, to stabilize the region there is a vital need for a forum whereby geopolitics can be discussed in the same way in which economics and globalization are discussed at the annual Asia Pacific Economic Cooperation (APEC) summits. However, Russia has long experience in great power politics and the complex security arrangements of the Cold War and its continuing legacy. It provides Russia with the necessary prerequisites to promote and help implement innovative proposals for a multilateral security dialogue across the region.

The writer used realism approach of International Relations theory define power implies victory in each interaction during the conflict. The writer sees the military operations in Crimean conflict as the strategic interaction of strong actor to defeat weak actor to increase their relative power. Also bring strategic interaction theory in this case to identify the ideal-types of strategies taken by states in pursuing their national interest. This strategy will distinct the approaches direct and indirect actors in implementing their operations and tactics on terrain which beneficial for the 
position. It establishes theories which apply in the framework, determining the level of analysis is very essential in this research as analytical tools. In international conflict, according to Waltz (1959), there are three levels of analysis: individual level, state level, and state system level. In association with this research, the writer uses the state system analysis in explaining the strategic interaction between Russia and Ukraine. This is to accommodate the Realist approach reflecting the actions taken due to the clash of interests among states in protecting their national security.

The strategic interaction theory explains why some asymmetric conflict could end quickly and how weak actors can asymmetric war over strong actors. In this theory, strategy refers to an actor's plan for using armed forces to achieve military or political objectives (Marsheimer, 1983: 28-29). Within this definition, the term strategy should be differentiated into two affiliated terms: grand strategy and tactics. Grand strategy is defined as the consolidation of diplomatic, economic, military, and political factors used by leaders to defend their respective nationstates (Skinner, 2015). While tactics defines as to the art of fight and along with the use of various arms of the military-for example, armor, artillery, and infantry-on terrain and favorable position. In order to acknowledge the ideal-type strategies, the typology is explained as follows (Toft, 2001: 100):

Attack (strong actor) strategies:

(1) direct attack

(2) barbarism

Defense (weak actor) strategies:

(3) direct defense

(4) guerrilla warfare strategy (GWS)

Based on the two distinct strategies, the approaches that are suitable in the strategic interaction classified into: direct and indirect. In direct approach, the focus is on targeting an adversary's armed forces in order to demolish the adversary's capacity to fight. While indirect approach seeks to demolish the adversary's will to fight: a guerilla warfare strategy target enemy soldiers, and barbarism targets enemy noncombatants (Toft, 2001: 105). If the same approach (direct-direct or indirect-indirect) occurs in the conflict, the weak actor will be defeated because there is no deflection of strong actor's power advantage. While in contrast, if opposite approach apply in the interactions (direct-indirect or indirectdirect), the victory for weak will indicate because the strong actor's power advantage is diverted or avoided (Toft, 2001: 105). There are 4 (four) premises are as follows:

First, in the context of direct attack versus direct defense, when strong actors attack using a direct strategy and weak actors defend using a direct strategy, all other 
things being equal, strong actors should win quickly and decisively;

Second, in the context of direct attack versus indirect defense, when strong actors attack with a direct strategy and weak actors defend using an indirect strategy, all other things being equal, weak actors should win;

Third, in the context of indirect attack versus direct defense, when strong actors attack with an indirect strategy and weak actors defend using a direct strategy, all other things being equal, strong actors should lose;

Fourth, in the context of indirect attack versus indirect defense, when strong actors employ barbarism to attack weak actors defending with a guerilla warfare strategy (GWS), all other things being equal, strong actor should win.

It concludes these premises describe an interaction based on the same-approach or opposite-approach. With strong actors are more likely to win same-approach interactions and lose opposite-approach interactions.

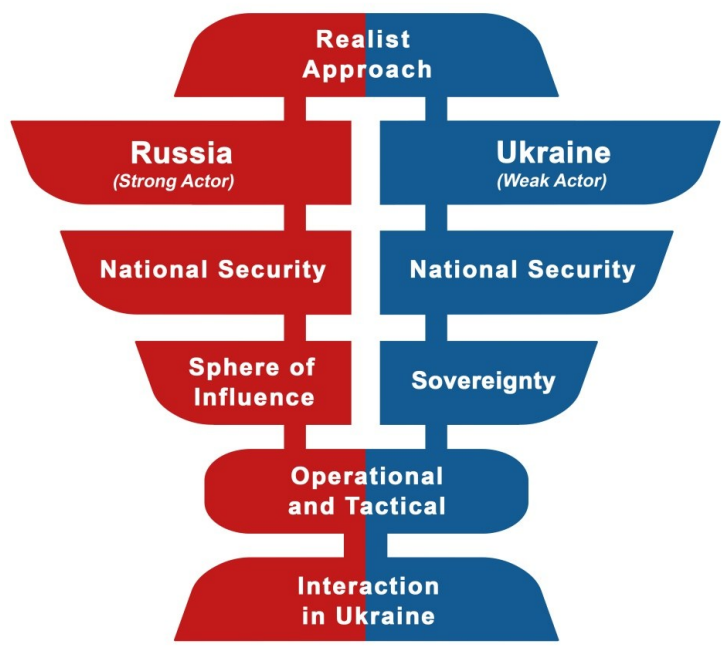

Figure 1 Russia-Ukraine Strategic Interaction
Russia is a regional strong actor versus Ukraine which perceived as a weak actor which conflicting interests in the protection of their national security. The clash of interest is affecting them to use its military power to pursuit their national interest. The writer identified that throughout strategic interaction occurring within the asymmetric conflict could be utilized in analyzing conditions of war that generate an outcome of states' actions in achieving their objectives.

\section{Conclusion}

The relative power of Russia as a strong actor in international system has determined its position to act assertively towards Ukraine. In regards to state behavior play a significance role in international system which reflected of Soviet Union era, Russia attempted to regain its sphere of influence over Ukraine-as. As result, a state implies power in victory. The behavior of Russia on this asymmetric warfare demonstrated Realist logic towards the protection of national security of the state. Realist logic becomes an integral part on Russia's military operation in Ukraine.

It remains as center of gravity for Russia in building a Eurasian integration ambition. EU enlargement policy on Ukraine illustrates a small shift taken by Ukraine to increase its power from Western part of the contingent. Political and economic provisions are recognized to be the elements of both 
entities' relations. Russia also still has several political measures to maintain. The importance of economic flow of energy transfer and natural resources, historic and symbolic (Crimea and Black Sea), military (defense industry and infrastructure of Russia Black Sea Fleet), and strategic geopolitical location are classified as the national interests of Russia over Ukraine.

From national perspective, Russia reformulates country's foreign and defense policy in order to maintain its survival. Particularly under the timeframe on 2000 until 2013, the revitalization process was become clearer on the stage. The willingness of Russia in return to change the world polarity architecture never is ignored. Russia renewed its foreign policy concept to maximizing presence on international system. Due to contemporary development, network diplomacy seems to be one of an effective solutions under these circumstances, including humanitarian and information technology. In addition, the reconstruction of Russian defense policy has strengthened state's capacity and capability in achieving the objectives. Additional consideration on Russia's military capability, the recognition of the advancement of cyber power, which begun since 2001 has signed a new dynamics of Russia's military operation. In the sense of combination between military and non-military forces, this new element is ready to be measured.

In the interaction between the two countries, Russia confirms its status as strong actor. Russia determines its national security components based on national goals, national balance of power, and degree of national security. On national goals, Ukraine perceived as a zone of Russian interest. Ukraine is not allowed to have a direct align with the EU because geopolitically it might hamper Russia's Eurasian interests; Protection of Russian compatriots in Ukraine has become a legitimate instrument for Russia in expanding its influence; Russia's energy transfer to Europe must be secured; and the existence of Russia Black Sea Fleet have to be maintained. 


\section{Bibliography}

\section{Books/Publications}

Bennet, A. (2014). Case Study Methods: Design, Use, and Comparative Advantages. Models, Numbers, and Cases: Methods for Studying International Relations, Eds. Detlef F. Sprinza \& Yael Wolinsky-Nahmias, Ann Arbor. University of Michigan Press.

Bukkvoll, T. (2001). Ukraine and the Black Sea Region, in Politics of the Black Sea: Dynamics of Cooperation and Conflict, ed. by T. Aybak. London and New York: I.B. Tauris.

Brzezinski, Z. (1997). The Grand Cheesboard. New York: Basic Books.

Clausewitz, C.V. (1827). On War. Book One. New Jersey, Princeton University Press.

Evans, G. \& Newnham J. (1998). The Penguin Dictionary of International Relations. London, UK: Penguin Books.

Garnett, S, W. (1997). Keystone in the Arch: Ukraine in the Emerging Security Environment of Central and Eastern Europe. Washington, DC. Carnegie Endowment for International Peace.

Giles, K. (June, 2015). Russia's Toolkit. See in, K. Giles, P. Hanson, R. Lyne, J. Nixey, J. Sherr, \& A. Wood. The Russian Challenge. Latimer Trend.

Giusti, S. \& Penkova, T. (2010). EU Policy toward Ukraine and Belarus: Diverging Paths? In Ther Foreign Policy of The European Union ed. Federiga Bindi. Washington, D.C.: Brooking Institution Press.

Jaworsky, J. I. (1995). Crimea's Importance to Ukraine and Its Future Security. In Crimea: Dynamics, Challenges, and Prospect, (ed.) by Maria Drohobycky. Lanham: Rowman \& Littlefield Publisher, Inc.

Jeffries, William W. (1967). Geography and National Power. Annapolis, United States Naval Institute.

Mankoff, J. (2009). Russian Foreign Policy: The Return of Great Power Politics. USA: Rowman \& Littlefield Publisher, Inc.

McLean, Iain. (1996). Oxford Concise Dictionary of Politics, Oxford, UK, University Press.

Mearsheimer, J.J. (1983). Conventional Deterrence. Ithaca, N.Y., Cornell University Press.

Mearsheimer, J.J. (2001). The Tragedy of Great Power Politics. New York: W.W Norton \& Company.

Morgenthau, H. (1948). Politics Among Nations. New York: Knopf.

Pelnens, G. (2009). The "Humanitarian Dimensions" of Russian Foreign Policy toward Georgia, Moldova, Ukraine, and the Baltic States. Riga.

Tal, Israel. (2000). National Security: The Israeli Experience. USA, CT, Praeger Publishers.

Saunders, S. (2010). Jane's Fighting Ships 2010-2011. Coulsdon, Jane's.

Schelling, T. (1966). Arms and Influence. New Haven, Connecticut, Yale University Press.

Sun Tzu, trans. Samuel B. Griffith. (1971). The Art War. London, Oxford University Press.

Sussex, M. \& Kanet, E.R. (2015). Russia, Eurasia and the Geopolitics of Energy: Confrontation and Consolidation. New York, USA. Palgrave Macmillan.

Waltz, K.N. (1979). Theory of International Politics. Reading MA, Addison-Wesley. 


\section{Journal Articles}

Connell, M.E. \& Evans, R. (2015, May). Russia's “Ambiguous Warfare” and Implications for the the U.S. Marine Corps. CNA.

Davydov, I. (2008, March). The Crimean Tatars and Their Influence on The 'Triangle of Conflict' - Russia-Crimea-Ukraine. California, Naval Graduate School.

Fisher, A. W. (1970). Introduction to the Russian annexation of the Crimea, 1772-1783. Cambridge: Cambridge University Press, $x i$.

Freeman, S.M. \& Solmirano, C. (2014, April). Trends in World Military Expenditure, 2013. Retrieved 8 December 2015, from SIPRI: http://books.sipri.org/files/FS/SIPRIFS1404.pdf.

Herz, J. (1950). Idealist Internationalism and the Security Dilemma. World Politics, 2(2), 157180.

Hodenskog, J. \& Pallin, C.V. (2013, December). Russian Military Capability in a Ten-Year Perspective - 2013. FOI.

Larrabee, S. F., Wilson, W. A. \& Gordon IV, J. (2015). The Ukrainian Crisis and European Security. Santa Monica, Calif: RAND Corporation.

Manurung, Hendra, (2013). Russia: The Asia Pacific Global Power. The President Post Indonesia. 7 January 2013. http://www.thepresidentpost.com/2013/01/07/russia-the-asia-pacificglobal-power, retrieved on 22 December 2017.

McLess, A. \& Rumer, E. (2014, July 30). Saving Ukraine;s Defense Industry. Carnegie Endowment for Peace.

Nichol, J. (2011, August 24). Russian Miliatary Reform and Defense Policy. Retrieved 7 December 2015, from Congressional Reserch Service: https:/www.fas.org/sgp/crs/row/ R42006.pdf.

Oliker, O., Crane, K., Schwartz, L.H., \& Yusupov, C. (2009). Russian Foreign Policy. Retrieved 12 December 2015, from: USA, RAND Cooperation.

Pamir, N.A. (2003). Energy and Pipeline Security in the Black Sea and Caspian Sea Regions: Challenges and Solutions. In The Black Sea Region: Cooperation and Security Building, ed. Oleksandr Pavluik and Ivanna Klympush-Tsintsadze. Armonk, New York: M. E. Sharp, Inc

SIPRI. (2013). SIPRI Arms Transfers Database. Retrieved January 5, 2015, from: http:// www.sipri.org/databases/armstransfers.

\section{Official Statements/Documents}

Brezhnev, L. (1968, November 13). Brezhnev Doctrine. Speech by First Secretary of the Soviet Union Leonid Brezhnev. International Relations and Security Network. ISN.

Maritime Doctrine of the Russian Federation 2020. (2001, July 27). Retrieved December 22, 2015, from Russian Ocean Policy 2020: http://www.oceanlaw.org/downloads/arctic/ Russian_Maritime_Policy_2020.pdf.

Medvedev, D. (2009, December 1). Speech at Third Russian World Congress of Compatriots Abroad. Retrieved January 7, 2016, from the President of Russia: http://en.kremlin.ru/ events/president/transcripts/48523.

Putin, V. (2006, May 10). Poslanie Federal'nomu Sobraniyu Rossiiskoi Federatsii. Retreived January 7, 2016, form Russian Federation Minstry of Foreign Affairs: http:// 
www.kremlin.ru/text/appears/2006/05/105546.shtml.

Putin, V. (2007, June 24). Speech at the Balkan Energy Cooperation Summit. Retrieved January 7, 2016, from the President of Russia: http://en.kremlin.ru/events/president/ transcripts/24368.

Putin, V. (2012). Rossiia i meniaiuchshiisia mir. Moskovskie novosti, 27 February. Retrieved February 27, 2012, from: http://www.mn.ru/politics/20120227/312306749.

Putin, V. (2014, March 18). Vladimir Putin Addressed State Duma Deputies, Federation Council Members, Heads of Russian Regions and Civil Society Representatives in The Kremlin. Retrieved January 7, 2016, from Russian Ministry of Foreign Affairs: http://en.kremlin.ru/ events/president/news/20603.

Russian Federation Military Doctrine. (2010, February 5). Retrieved December 22, 2015, from The School of Russian and Asian Studies: http://www.sras.org/ military_doctrine_russian_federation_2010.

Russian Federation Ministry of Defence. (2013a). Sukhoputnye voiska. Retrieved January 1, 2016, from Russian Federation Ministry of Defence: http://structure.mil.ru/structure/ forces/ground/structure.htm.

Russian Federation Ministry of Defence. (2013b). Vozdushno-desantnye Voiska. Retrieved August 7, 2013, from Russian Federation Ministry of Defence: http://structure.mil.ru/ structure/forces/airborne.htm.

Russian Federation Ministry of Defence. (2013c). Raketnye voiska strategicheskogo naznacheniia. Retrieved 16 September 2013, from Russian Ministry of Defence: http:// structure.mil.ru/structure/forces/rd/strategic_rocket.htm and http://structure.mil.ru/ structure/forces/strategic_rocket.htm.

Russian Federation Ministry of Foreign Affairs. (2013, February 18). Concept of the Foreign Policy of the Russian Federation. Retrieved September 4, 2015, from Russian Federation Ministry of Foreign Affairs: http://archive.mid.ru// brp_4.nsf/0/76389FEC168189ED44257B2E0039B16D.

Russian Federation Ministry of Foreign Affairs. (2014, April 8). Article of the Russian Federation Minister Sergey Lavrov "It's not Russia that is destabilizing Ukraine." Retreived December 10, 2015, from Russian Federation Ministry of Foreign Affairs: http:// www.mid.ru/en/foreign_policy/news/-/asset_publisher/cKNonkJE02Bw/content/id/66734.

Russian Federation Ministry of Foreign Affairs. (2014, August 29). Statement by the Russian Ministry of Foreign Affairs on the events in Ukriane. Retrieved January 7, 2016, from Russian Ministry of Foreign Affairs: http://archive.mid.ru//bdomp/brp_4.nsf/ e78a48070f128a7b43256999005bcbb3/660ea8ecf9378e3a44257d430060c61f! OpenDocument.

\section{Online Resources}

BBC News. (2014, March 16). Crimea Referendum: Voters 'Back Russia Union.' Retrieved December 23, 2015, from BBC: http://www.bbc.com/news/world-europe-26606097.

BBC News. (2014, April 7). Ukraine: Pro-Russians storm offices in Donetsk, Luhansk, Kharkiv. Retrieved December 23, 2015, from BBC: http://www.bbc.com/news/world-europe26910210.

BBC News. (2014, April 16). Ukraine Says Donetsk 'Anti-Terror Operation' Under Way. 
Retrieved January 6, 2016, from BBC: http://www.bbc.com/news/world-europe27035196.

BBC News. (2014, June 7). Profile: Ukraine's President Petro Poroshenko. Retrieved October 4, 2015, from BBC News: http://www.bbc.com/news/world-europe-26822741.

CIA. The World Factbook. Retrieved 16 November 2017, from CIA: https://www.cia.gov/library/ publications/the-world-factbook/geos/up.html.

Kissinger, H. (2014, March 6). How the Ukraine crisis ends. Retrieved 15 November 2017, from The Washington Post: https://www.washingtonpost.com/opinions/henry-kissinger-to-settle -the-ukraine-crisis-start-at-theend/2014/03/05/46dad868-a496-11e3-8466d34c451760b9_story.html

Russia Today. (2014, February 27). Russian flag over Crimea's parliament as people barricaded inside. Retrieved December 23, 2017, from RT: https://www.rt.com/news/crimeaparliament-building-capture-987.

Russia Today. (2014, March 1). Putin: Russian citizens, troops threatened in Ukraine, need armed forces' protection. Retrieved December 29, 2017, from RT: https://www.rt.com/news/ russia-troops-ukraine-possible-359.

TASS (2016). Gas Pipelines to Europe by 2018. Retrieved November 27, 2017, from TASS, Russian News Agency: http://tass.ru/en/infographics/7275.

Ukraine Policy. (2014, February 27). Russian Seize Simferopol. Retrieved October 8, 2017, from Ukraine Policy: http://ukrainianpolicy.com/russians-seize-simferopol.

Ukrainian Policy. (2014, March 1). Russian Invasion of Ukraine. Retrieved Oktober 8, 2017, from Ukrainian Policy: http://ukrainianpolicy.com/russian-invasion-of-ukraine. 